\section{THE ORIENTATION OF THE ANCIENT} CHURCHES OF IRELAND. ${ }^{1}$

PROF. J. P. O'REILLY'S paper, although mainly antiquarian, presents certain points of scientific interest worth attention for their novelty and possible application elsewhere. The two churches in question are easily accessible from Dublin, but they have not been fully and sufficiently examined. The author examines what is known of the saint to whom both the churches are said to be dedicated, giving citations from the public records relative to the saint's name and its various forms. He shows that there are at least four different saints of the name of Begga mentioned having different festival days, and points out the admitted uncertainty existing as to the dedicatory saint in question. As a solution, he takes into account the orientation of Dalkey Town Church, assuming that the church was oriented to the rising sun of the saint's festival day. The older or western part of the church is oriented E. $8^{\circ} \mathrm{Io}^{\prime} \mathrm{N}$., while the newer or eastern part or chancel has that of E. $9^{\circ} 30^{\prime} \mathrm{N}$. $\mathrm{He}$ finds the sun to present a northing corresponding to these figures between April II and $I_{5}$ on his passage northward, and between August 29 and September 2 on his passage southwards. "As regards," he says, "the festivals of saints mentioned as occurring between August 29 and September 2, the nearest in date would be that of St. Bega (September 3) (the saint venerated at Dunbar)." Hence he draws the conclusion that she was the particular St. Bega to whom the church was de'ficated.

Prof. O'Reilly then considers the church on Dalkey Island, points out its remarkable position, gives the details of its structure, and argues that the belfry (so called) was most probably used as an observatory for the determination of the equinox in particular, and for the observation of the stars so as to fix the hours of service. This argunent he supports by several citations and a description of the meridian line, with inscriptions, existing in St. Sulpice Church, Paris. He then compares the south-east window now existing in the Dalkey Island church with that of Dalkey Town Church, and shows their close relation in certain respects. This leads to a detailed examination of the south-east opening of Dalkey Town Church, its dimensions and probable use, for the determination of the saints' festival day by the stoppage of the sunlight rays through it at certain times of the year. He shows that this would happen for one of the compartments of the window on April 9 and September 4 , so that here again the festival day of St. Bega of Dunbar is pointed out. As regards the orientation of Dalkey Island church, he shows that it is about E. $3^{\circ}$ south, not due east. He explains this error from the nature of the ground as previously described, and further points out how the true east and west line is given, and was apparently fixed, by a line passing through a Greek cross carved on a rock opposite the western door, and the north-west angle of the church. Lastly, his measures having been made metrically, he finds that the unit of measurement used in the building was the Spanish "Vara" $=0.835 \mathrm{~m}$., and gives proofs of this. He thus raises the broad and interesting question of the unit or units of measurement having been in use in Ireland previous to the adoption of the British standard of feet and inches, and invites further investigation in this respect.

\section{UNIVERSITY AND EDUCATIONAL INTELLIGENCE.}

Cambridge.-Mr. W. H. Young, Peterhouse, has been approved for the degree of Doctor of Science.

A vacancy for a university lecturer in histology has been caused by the election of Dr. Langley to the chair of physiology. The appointment will be made in the Lent term, 1904 .

Dr. Dickinson, Dr. Rolleston, and Dr. Kellock have been appointed additional examiners for medical degrees on account of the large number of candidates in the present term.

1 " Notes on the Orientations and Certain Architectural details of the Old Churches of Dalkey Town and Dalkey Island, Dublin." By Prof. Jos. P. O'Reilly. Abstract of paper read before the Royal Irish Academy, February 23 .

$$
\text { NO. I780, VOL. 697 }
$$

The Walsingham medal for biology has not been awarded this year

The Sheepshanks astronomical exhibition is awarded to Mr. P. E. Marrack, one of the senior wranglers of the year.

The observatory syndicate proposes that the office of assistant director of the observatory should be conferred on Mr. H. F. Newall, who has been observer since 1890 , without stipend.

The graces for the organisation of the school of geography were opposed in the Senate on December 5, but were carried by large majorities. A board of studies, a special examination for the ordinary B.A. degree, and a diploma in geography are thereby established.

Sir William Mather will distribute the prizes at the Merchant Venturers' Technical College, Bristol, on Thursday, December 17 .

A GIFT of $50,000 l$. has been made by an anonymous donor to University College, London, through Prof. Starling, to be used by the council of the college for the promotion of higher scientific education and research at that institution.

Mr. John D. Rockefeller has, we learn from Science, offered to give Vassar College $40,000 l$, , or such part of this sum as may be equalled by gifts from other sources before June, 1904. I0, oool. has so far been subscribed, and an appeal is made for further gifts.

THE annual meeting of the Association of Technical Institutions will be held at the Leathersellers' Hall, London, on Friday, January 29, 1904. Sir John Wolfe Barry, K.C.B., F.R.S., will occupy the chair, and an address will be given by the president-elect, the Right Hon. Sir John E. Gorst, K.C., M.P.

IT is announced from New York that the committee to control the selection for the Rhodes scholarships available for Americans has been formed. The presidents of Yale and Harvard Universities are the principal members of the committee, which also includes one representative from each State in the Union.

The University of Ottawa was totally destroyed by fire on December 2. More than five hundred students from all parts of Canada, the United States, and Mexico were in residence. Fortunately they escaped, but several professors were injured, none, however, fatally. Everything in the building was destroyed, the total loss being estimated at 500,000 dollars.

THE first meeting of the court of the University of Liverpool was held on December 5, when Sir Edward Lawrence, Pro-Chancellor, presided. During the course of an address, proposing the adoption of the report and accounts, the chairman said the university had started its career with a property in land, buildings, and investments having a value of more than $500,000 l$. The subscriptions to the university movement in Liverpool amount to $170,000 l$.

A confernnce was held on December 4 between the consultative committee of the Board of Education and representatives of various professional bodies in order to discuss the desirability and feasibility of the introduction of a system of school leaving certificates for England. Similar conferences with representatives of universities and of the teaching profession have previously been held. Lord Londonderry attended the conference for a short time in order to say a few words on behalf of the Board of Education. Sir W. Hart Dyke subsequently took the chair.

Mr. R. B. Haldane, K.C., M.P., presented the prizes and certificates at the Borough Polytechnic, Southwark, on December 4. In the course of his address, Mr. Haldane said that with regard to the movement for the creation of a great school of technology in London, there had been a certain amount of mystery as to its relation to polytechnics and its position generally. The reason that nothing had yet been disclosed was because things were moving, but with such deliberation that it was inexpedient to present pictures of the end when they had not got much beyond the beginning. They were only in the early stages at the present time. Conferences were taking place with various 